\title{
Spatial concentration of geomorphological heritage elements in Guaritas do Camaquã geomorphosite (Rio Grande do Sul - Brazil)
}

\author{
Concentração espacial dos elementos do patrimônio geomorfológico no \\ geomorfossítio Guaritas do Camaquã (Rio Grande do Sul-Brasil)
}

Márlon Roxo Madeira 1, Edvania Aparecida Correa Alves ${ }^{2}$ e Adriano Luís Heck Simon ${ }^{3}$

1 Universidade Federal de Santa Maria, Programa de Pós-Graduação em Geografia, Santa Maria, Brasil.

E-mail: marlonmadeira@hotmail.com

ORCID: https://orcid.org/0000-0002-7604-8540

2 Universidade Federal de Pelotas, Departamento de Geografia, Pelotas, Brasil.

E-mail: edvania.alves@ufpel.edu.br

ORCID: https://orcid.org/0000-0002-0712-5055

3 Universidade Federal de Pelotas, Departamento de Geografia, Pelotas, Brasil.

E-mail: adriano.simon@gmail.com

ORCID: https//orcid.org/0000-0003-2888-308X

Recebido: 15/05/2020; Aceito: 28/09/2020; Publicado: 10/04/2021

\begin{abstract}
Geomorphological mapping of geomorphosites should allow the identification and characterization of the landforms that comprise the geoheritage of these places and demand actions of geoconservation and geotourism. The objective of this study was to identify and analyse the areas with the largest spatial concentration of landforms that comprises the geomorphological heritage elements in Guaritas do Camaquã geomorphosite - Rio Grande do Sul state - Brazil. Using as the starting point the geomorphological map $(1: 50,000)$ produced by Santos $(2016)$, the following methodological procedures were performed: (a) selection of the vector data from the geomorphological map and their conversion to raster data; (b) classification of raster data regarding the values of spatial concentration of the geomorphological features into null, very low, low, medium, high and very high; (c) individualization and reclassification of the very high and high values of spatial concentration of the geomorphological features (given value 1), and the other values (given value 0); and (e) overlap of information with value (1) to verify the spatial coexistence of areas with high concentration of geomorphological features. The results allowed to identify the location and the extension of the areas where high concentrations of geomorphological features coexist, and to identify the geomorphological heritage elements that demand priority in geoconservation actions. Some of these geomorphological heritage elements are already part of geotouristic routes, as Pedra das Guaritas, while others are isolated and little explored. Such spatial arrangements of the landforms must be incorporated to the geotouristic routes to integrate the geomorphological heritage elements present in the geomorphosite.
\end{abstract}

Keywords: geomorphological mapping; geoheritage; geoprocessing.

Resumo: A cartografia geomorfológica de geomorfossítios deve permitir a identificação e caracterização das formas do relevo que compõem o geopatrimônio e demandam ações de geoconservação e geoturismo. Este trabalho teve como objetivo identificar e analisar as áreas que possuem maior concentração espacial do das formas do relevo que compõem os elementos do patrimônio geomorfológico no geomorfossítio Guaritas do Camaquã - estado do Rio Grande do Sul - Brasil. A partir do mapa geomorfológico (1:50.000) elaborado por Santos (2016), foram realizados os seguintes procedimentos metodológicos: (a) seleção dos dados vetoriais do mapeamento geomorfológico e conversão dos mesmos para formato raster; (b) classificação 
das informações raster das feições geomorfológicas em valores de concentração espacial nulo, muito baixo, baixo, regular, alto e muito alto; (c) individualização e reclassificação dos valores alto e muito alto de concentração espacial das feições geomorfológicas (valor 1) e dos demais valores de concentração espacial (valor 0); e (e) sobreposição das informações com valor (1) a fim de verificar a coexistência espacial das formas do relevo em áreas de elevadas concentrações das feições geomorfológicas. Os resultados permitiram identificar a localização e a extensão das áreas onde coexistem altas concentrações espaciais do patrimônio geomorfológico, atuando na organização de elementos do patrimônio geomorfológico que demandam ações prioritárias de geoconservação. Alguns destes elementos já estão inseridos em roteiros geoturísticos, como no caso da Pedra das Guaritas, enquanto outros se encontram isolados e pouco explorados. Tais arranjos espaciais de formas do relevo precisam ser incorporados aos roteiros geoturísticos para integrar, de fato, o patrimônio geomorfológico presente no geomorfossítio.

Palavras-chave: cartografia do relevo; geopatrimônio; geoprocessamento.

\section{Introduction}

The magnitude, singularity, rarity, representativeness, beauty, grandiosity and spectacularity of landforms are the focuses of geodiversity studies, both in local and regional scales (CUNHA; VIEIRA, 2004; THOMAS, 2011; THOMAS, 2012). Moreover, according to Gray, Gordon e Brown (2013), the landforms also have an important role in supporting ecosystems and environmental and social services.

The geomorphological heritage comprises a series of geomorphological features and processes that are relevant as structuring factors of the landscape, and as a tool to understand the history of the Earth (VIEIRA; CUNHA, 2004; FIGUEIRÓ; VIEIRA; CUNHA, 2013, CORATZA; HOBLÉA, 2018). Therefore, it should be protected and passed on to future generations (REYNARD, 2009; RODRIGUES; FONSECA, 2010; REYNARD; CORATZA, 2016).

The word "geomorphosite" has been used to define either the simplest landforms or the widest landscapes that have as their main features: scenic beauty, social economical potential, scientific-pedagogical and cultural relevance, and are part of the geomorphological heritage (PANIZZA, 2001). Santos et al. (2019, p. 2046) suggest that:

Concerning the spatial scale, geomorphosites may be punctual occurrences with only a few square meters, such as small dolines or tafonis; may have aligned forms with several hundred meters, such as meandering rivers; or may consist of great dimension areas, such as mountain massifs or great barrier islands. (SANTOS et al. 2019, p. 2046).

Reynard (2009) and Panizza (2001) have asserted that geomorphosites are vulnerable and would need protective and management measures that would begin by the characterization of the landforms. Furthermore, Coratza; Hobléa (2018) reiterated the idea above and stated that geomorphosites mapping is a key action to further characterization, research and protection of the geomorphological heritage. These authors also suggested that maps, different from the classic geomorphological ones, should be produced, as they would allow professionals from different areas to understand them.

The geomorphological mapping of geomorphosites should allow the identification and characterization of the main sets of forms that comprise the geoheritage of the area, as they are the targets of the actions of geoconservation and geotourism (CARTON; CORATZA; MARCHETTI, 2005; VON AHN; SIMON, 2017). However, the complexity of such documents results in a large quantity of data and symbols associated to them, giving rise to qualitative thematic maps that lose their potential when used in quantitative evaluations (MELELLI et al., 2017).

The set phenomenon attached to the relief forms establishes spatial relations on the Earth surface, creating different patterns of organization (MEDEIROS; CÂMARA, 1998; CÂMARA et al., 2004). Within this context, geoprocessing is a tool used to identify and spatially analyse such phenomenon, helping to understand and refine the spatial information of the geomorphological phenomenon that takes place in a certain area (BURROUGH, 1986; MEDEIROS, 2012). Therefore, geoprocessing can be used to guide the actions of environmental planning that, in the scopus of geomorphologic heritage, have been used in geoconservation and geotourism. 
Finally, this study was developed with the aim of analysing the areas that have the highest spatial concentration of geomorphological heritage elements in the Guaritas do Camaquã geomorphosite - Rio Grande do Sul state - Brazil, as these areas are competing for priority actions of geoconservation and geotourism.

\section{Material and Methods}

\subsection{Study area}

The Guaritas do Camaquã geomorphosite has about $230 \mathrm{~km}^{2}$, being located on the borders of Caçapava do Sul and Santana da Boa Vista municipalities, in Rio Grande do Sul State, Brazil (Figure 1).

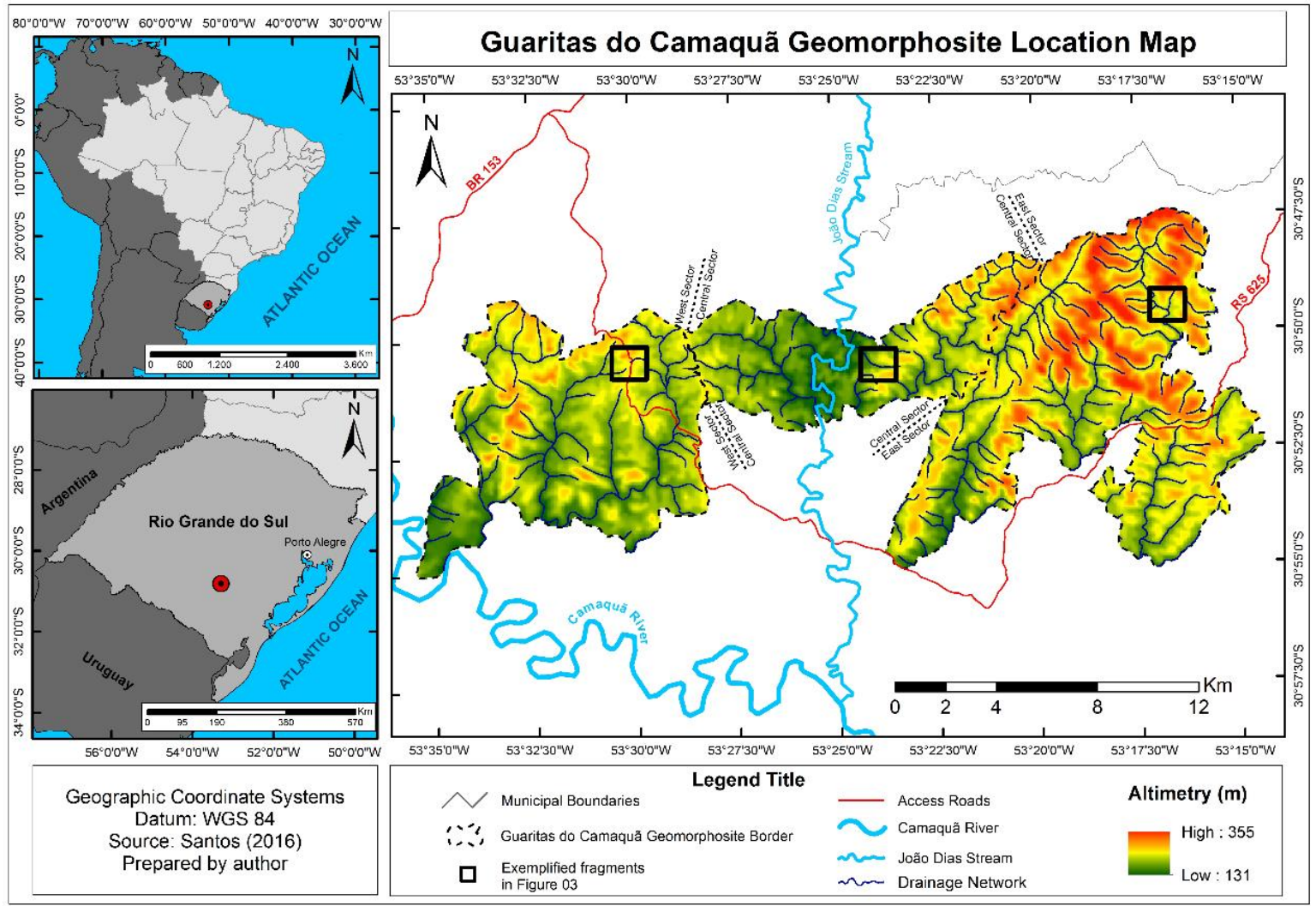

Figure 1. Location of the Guaritas do Camaquã geomorphosite (RS - Brazil).

It is situated in the Camaquã Sedimentary Basin (CSB) and comprises a set of residual landforms that result in an attractive area with a singular landscape (PAIM; FALLGATTER; SILVEIRA, 2010) recognized by its aesthetic value, which is of particular importance for tourism and/or the educational use of the site. The Camaquã Sedimentary Basin is characterized by a thick accumulation (of approximately 6,000 to 7,000 meters) of sedimentary units with distinct morphogenetic characteristics that are delimitated by angular and erosive discordances of regional character (PAIM; FALLGATTER; SILVEIRA, 2010; PEREIRA, 2011; SANTOS, 2016).

Paim e Lopes (2000) showed the presence of different allostratigraphic units in CSB that were originated in periods between depositional events (accumulation of thick sedimentary and volcanic-sedimentary packages) and intervals with the predominance of erosional processes. These allostratigraphic units are characterized, from the base to the top, in: Maricá Allogroup (620 e $592 \mathrm{Ma}$ ); Bom Jardim Allogroup (592 e $573 \mathrm{Ma}$ ); Cerro do Bugio Allogroup (573 e $559 \mathrm{Ma}$ ); Santa Bárbara Allogroup (559 e $540 \mathrm{Ma}$ ); and Guaritas Allogroup (470 e $19 \mathrm{Ma}$ ) (PAIM; LOPES, 2000; PAIM; FALLGATTER; SILVEIRA, 2010; CHEMALE, 2000).

The Guaritas Allogroup refers to the allostratigraphic unit of the CSB exposed in the Guaritas do Camaquã Geomorphosite (Figure 2). It is approximately 800 meters thick and characterized by eolian deposits interlayered with basic to intermediate lava at the base and fluvial-deltaic deposits in the upper intervals (PAIM; FALLGATTER; SILVEIRA, 2010). This segment is comprised by Pedra Pintada and Varzinha alloformations, which have approximately 400 meters each. 
The Pedra Pintada Alloformation is composed by three eolian packages (dunes/inter dunes facies associations), laterally associated with fluvial-lacustrine-deltaic deposits and proximal (fault border) alluvial fan strata (PAIM; SCHERER, 2007; PAIM; FALLGATTER; SILVEIRA, 2010; MARASCHIN et al., 2010) (Figure 2).

Varzinha Alloformation is composed by alluvial strata followed by eolian accumulation at the base and covered by a lacustrine succession and associated deltas. The eolian interval is an heritage of a paleo-desert generated by winds in opposite direction (S-SW) to the pattern of the predominant circulation in the deposition of Pedra Pintada Alloformation (Figure 2).

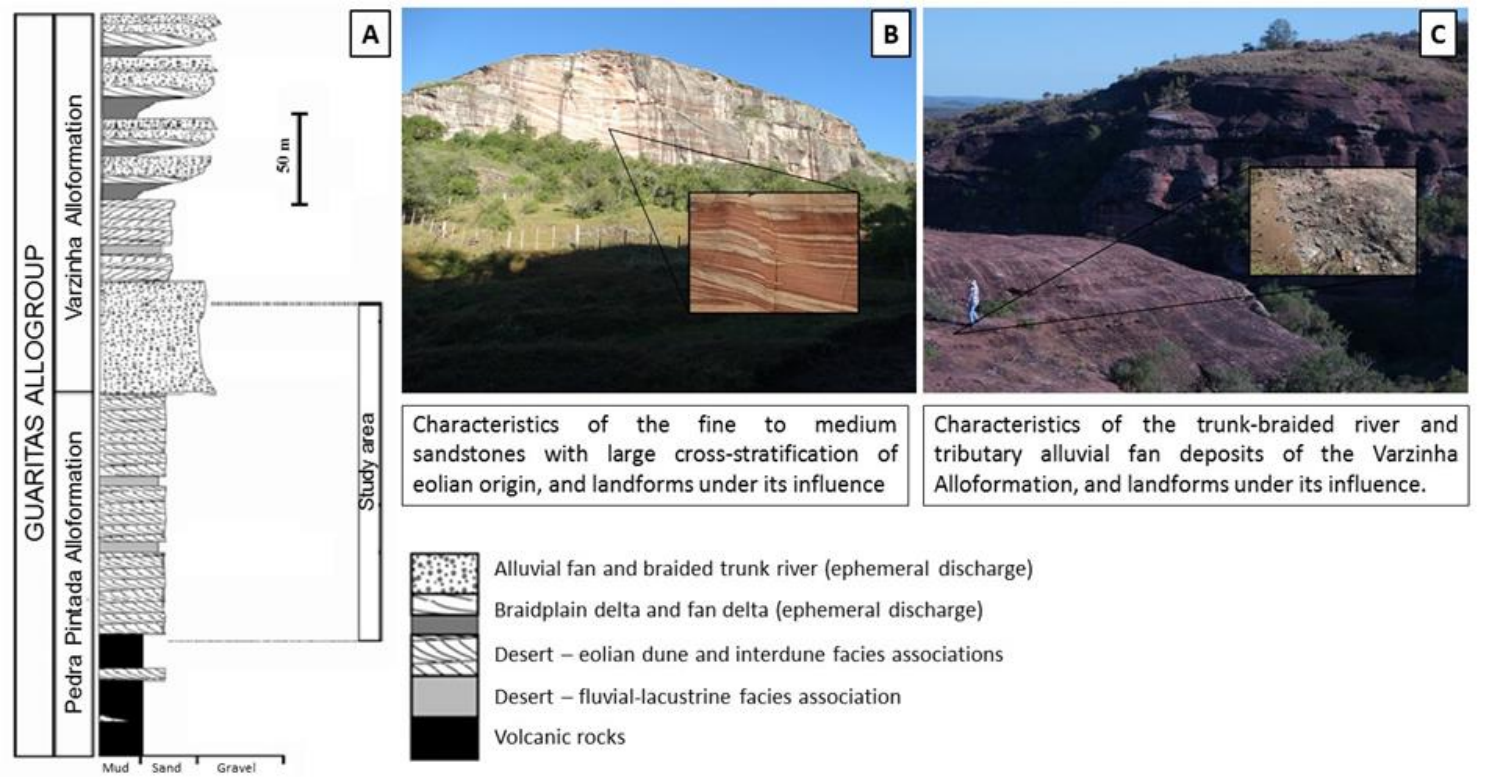

Figure 2. (A) Stratigraphic column of Guaritas Allogroup. It indicates the interval exposed in Guaritas do Camaquã Geomorphosite; (B) Aspects of Pedra Pintada Alloformation; (C) Aspects of Varzinha Alloformation. Source: adapted from Paim, Fallgatter e Silveira (2010), images from the authors.

The geomorphological characteristics of the area presents singularities that resulted from the geological complexity previously exposed. There is the predominance of ruiniform features, which were the result of pluvial erosional processes, with the occurrence of fluvial canals that act on a fractured and horizontal sedimentary substrate (PAIM; FALLGATTER; SILVEIRA, 2010).

The geological-geomorphological evolution of CSB was conditioned by a succession of dry and humid climates (SANTOS, 2016). Such changes acted on the formation of the ruiniform landforms of the area. Nowadays, there is the predominance of the temperate subtropical type climate of the State of Rio Grande do Sul. The average temperatures vary from $22.1^{\circ}$ (in January) to $12.2^{\circ}$ (between June and July) (RIO GRANDE DO SUL, 2010).

\subsection{Methodological Procedures}

2.2.1 Geomorphological mapping as the starting point to the analysis of the spatial concentration of the landforms

The analysis of the spatial concentration of geomorphological heritage elements in the Guaritas do Camaquã geomorphosite was done with the help of the vector data from geomorphological mapping in a scale of 1:50.000 (SANTOS 2016). This map followed the methodology suggested by Cunha (2001) and Cunha, Mendes e Sanchez (2003), who adapted the geomorphological mapping symbology from Tricart (1965) and Verstappen; Zuidam (1975). Cunha (2001) proposed a label for geomorphological mapping used in environmental management and, therefore, suitable to the geoconservation context.

The geomorphological mapping produced by Santos (2016) emphasized the use of morphography to characterize the landforms of the geomorphosite. This study provided basic information about the geomorphological constituents of the area, mainly regarding the landforms that have higher relevance as geotouristic attractions (BORBA, 2011). 
Vector data derived from this mapping may be treated and related in GIS environment. Such treatment of the data gives precise answers about the spatial concentration of the landforms that are part of the geomorphological heritage and subsides strategies of geoconservation, geotourism and environmental monitoring.

Santos (2016) performed a geomorphological mapping in three sectors (central sector, west border sector and east border sector - indicated in Figure 1). These sectors were defined according to the litho-morphological conditions of the studied area. Therefore, the same sectors of analysis were kept to analyse the spatial concentration of the landforms proposed for this study.

Figure 3 shows the following examples: (A) fragments of the geomorphological map elaborated by Santos (2016); (B) the altimetry under which the features are organized; and (C) the preliminary data obtained after the techniques of analysis of the spatial concentration of the geomorphological heritage elements were applied. Such techniques will be further detailed.
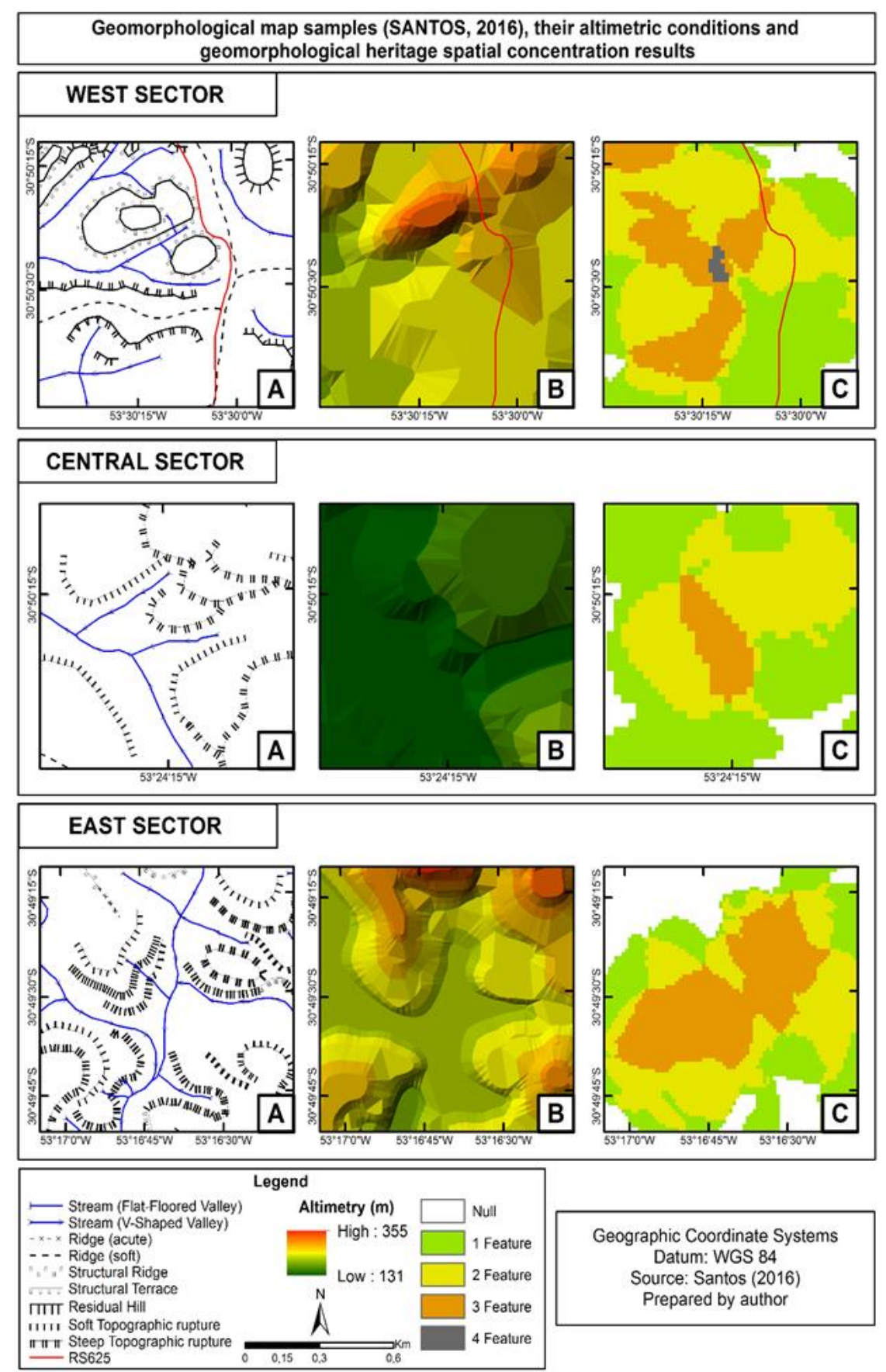

Figure 3. Fragments of the examples: (A) fragments of the geomorphological map elaborated by Santos (2016); (B) Altimetry; (C) Fragments of the preliminary data of the spatial concentration of the geomorphological heritage elements. 
2.2.2 Vector data selection from geomorphological map and its conversion to raster data

The extension Spatial Analyst of the software Arc.Gis 10.1 was used to select and convert the vector data of the geomorphological map from Santos (2016). The following geomorphological features information layers were selected: structural terraces; topographic ruptures (steep and soft); structural ridges; residual hills; ridges (soft and acute); and streams (flat-floored valley and V-shaped valley).

The selection of these features resulted in a map of continuous representation of the landforms spatial concentration. This map was produced using the density line tool present in the Spatial Analyst/Density extension (ESRI, 2013). Each of these geomorphological features was classified according to the spatial concentration values, ranging from null (when there is no geomorphological features), very low, low, medium, high and very high (SOUZA et al., 2013) (Figure 4).

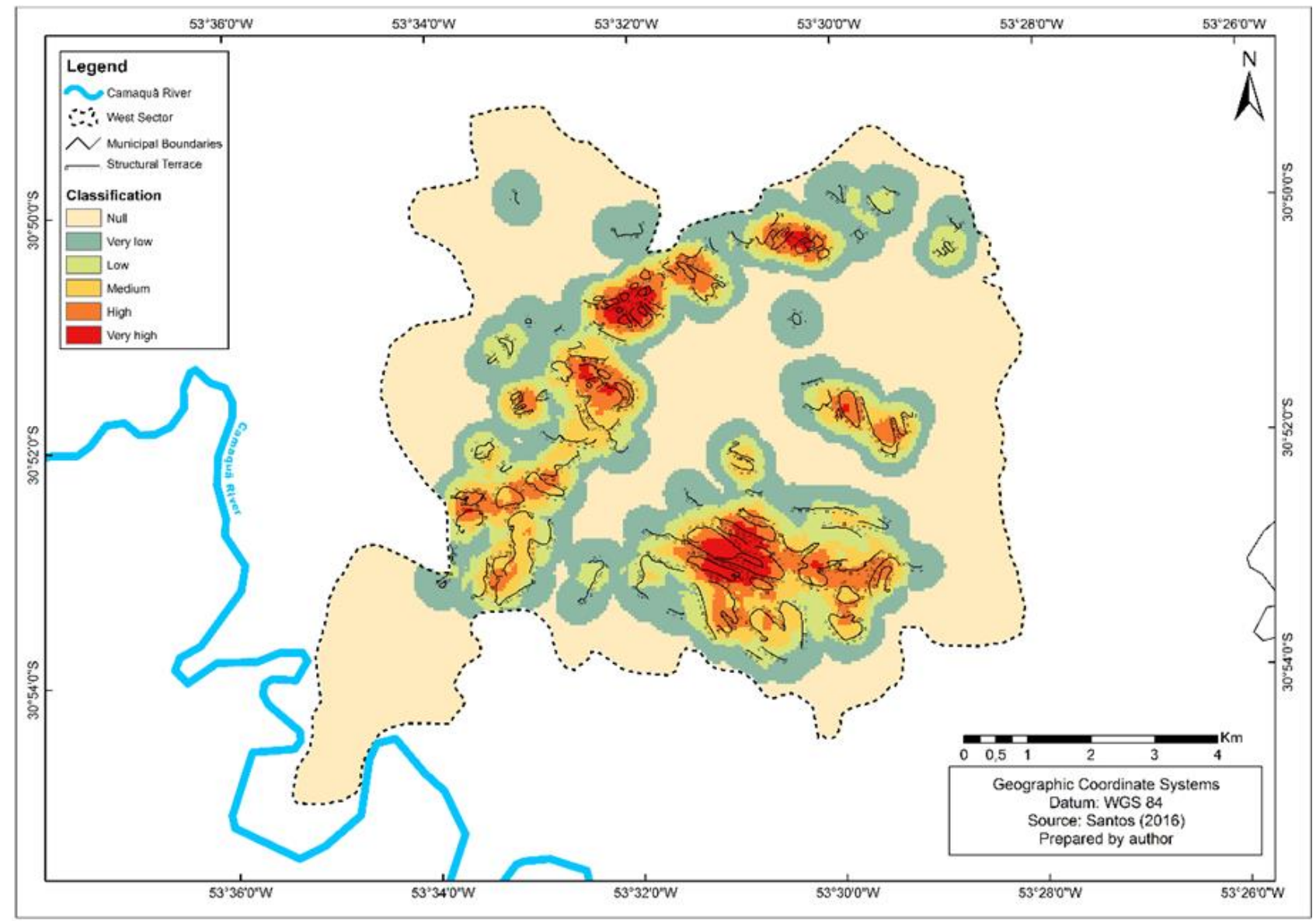

Figure 4. Example (structural terraces from the west sector of Guaritas do Camaquã geomorphosite) of the overlap of vector data (SANTOS, 2016) and raster data (classified according the spatial concentration values). The same procedure was performed to the other geomorphological features.

The natural breaks method (ESRI, 2013) defined the spatial concentration values of the geomorphological features mentioned above. The input values used referred to the line lengths (meters) of the selected landforms (Table 01 and Figure 5). 
Table 1. Length (meters) of the geomorphological features (vector format) and classification of the features using the natural breaks.

\begin{tabular}{|c|c|c|c|c|c|c|}
\hline \multirow{2}{*}{$\begin{array}{l}\text { Geomorphological Features } \\
\text { (West Sector) }\end{array}$} & \multicolumn{5}{|c|}{ Length (meters) } & \multirow[b]{2}{*}{ Total Length } \\
\hline & $\begin{array}{l}\text { Very } \\
\text { low }\end{array}$ & Low & Medium & High & Very high & \\
\hline Soft Topographic rupture & 839 & 1.399 & 2.019 & 2.799 & 5.099 & 12.155 \\
\hline Steep Topographic rupture & 887 & 1.582 & 2.397 & 3.500 & 6.114 & 14.480 \\
\hline Structural Terrace & 1.652 & 2.833 & 4.092 & 5.745 & 10.035 & 24.357 \\
\hline Residual Hill & 865 & 1.382 & 1.899 & 2.371 & 2.865 & 9.382 \\
\hline Structural Ridge & 633 & 1.001 & 1.462 & 2.049 & 2.935 & 8.080 \\
\hline Ridge (soft) & 1.022 & 1.672 & 2.399 & 3.245 & 5.016 & 13.354 \\
\hline Ridge (acute) & 571 & 912 & 1.350 & 2.006 & 3.101 & 7.940 \\
\hline Stream (V-Shaped Valley) & 1.692 & 2.444 & 3.223 & 4.137 & 6.850 & 18.346 \\
\hline Stream (Flat-Floored Valley) & 934 & 1.533 & 2.203 & 3.013 & 4.494 & 12.177 \\
\hline \multirow{2}{*}{$\begin{array}{l}\text { Geomorphological Features } \\
\text { (Central Sector) }\end{array}$} & \multicolumn{5}{|c|}{ Length (meters) } & \\
\hline & Very low & Low & Medium & High & Very high & Total Length \\
\hline Soft Topographic rupture & 1.046 & 1.790 & 2.698 & 4.076 & 7.022 & 16.632 \\
\hline Steep Topographic rupture & 1.409 & 2.315 & 3.322 & 4.765 & 8.557 & 20.368 \\
\hline Structural Terrace & 1.658 & 2.789 & 4.032 & 5.691 & 9.611 & 23.781 \\
\hline Residual Hill & 1.329 & 2.186 & 2.956 & 3.655 & 4.460 & 14.586 \\
\hline Structural Ridge & 883 & 1.495 & 2.141 & 3.059 & 4.333 & 11.911 \\
\hline Ridge (soft) & 1.258 & 2.097 & 3.160 & 4.614 & 7.131 & 18.260 \\
\hline Ridge (acute) & 942 & 1.557 & 2.249 & 3.268 & 4.902 & 12.918 \\
\hline Stream (V-Shaped Valley) & 2.319 & 3.387 & 4.565 & 5.964 & 9.388 & 25.623 \\
\hline Stream (Flat-Floored Valley) & 1.369 & 2.201 & 3.032 & 4.011 & 6.237 & 16.850 \\
\hline \multirow{2}{*}{$\begin{array}{c}\text { Geomorphological Features } \\
\text { (East Sector) }\end{array}$} & \multicolumn{5}{|c|}{ Length (meters) } & \\
\hline & Very low & Low & Medium & High & Very high & Total Length \\
\hline Soft Topographic rupture & 1.054 & 1.819 & 2.821 & 4.192 & 6.723 & 16.609 \\
\hline Steep Topographic rupture & 2.041 & 3.440 & 5.190 & 7.697 & 14.871 & 33.239 \\
\hline Structural Terrace & 2.994 & 4.931 & 6.927 & 9.393 & 14.971 & 39.216 \\
\hline Residual Hill & 578 & 875 & 1.219 & 1.649 & 1.993 & 6.314 \\
\hline Structural Ridge & 458 & 727 & 1.019 & 1.430 & 2.015 & 5.649 \\
\hline Ridge (soft) & 1.407 & 2.228 & 3.226 & 4.457 & 7.478 & 18.796 \\
\hline Ridge (acute) & 836 & 1.460 & 2.190 & 3.080 & 4.540 & 12.106 \\
\hline Stream (V-Shaped Valley) & 2.162 & 2.831 & 3.500 & 4.324 & 6.563 & 19.380 \\
\hline Stream (Flat-Floored Valley) & 505 & 842 & 1.165 & 1.458 & 1.868 & 5.838 \\
\hline
\end{tabular}




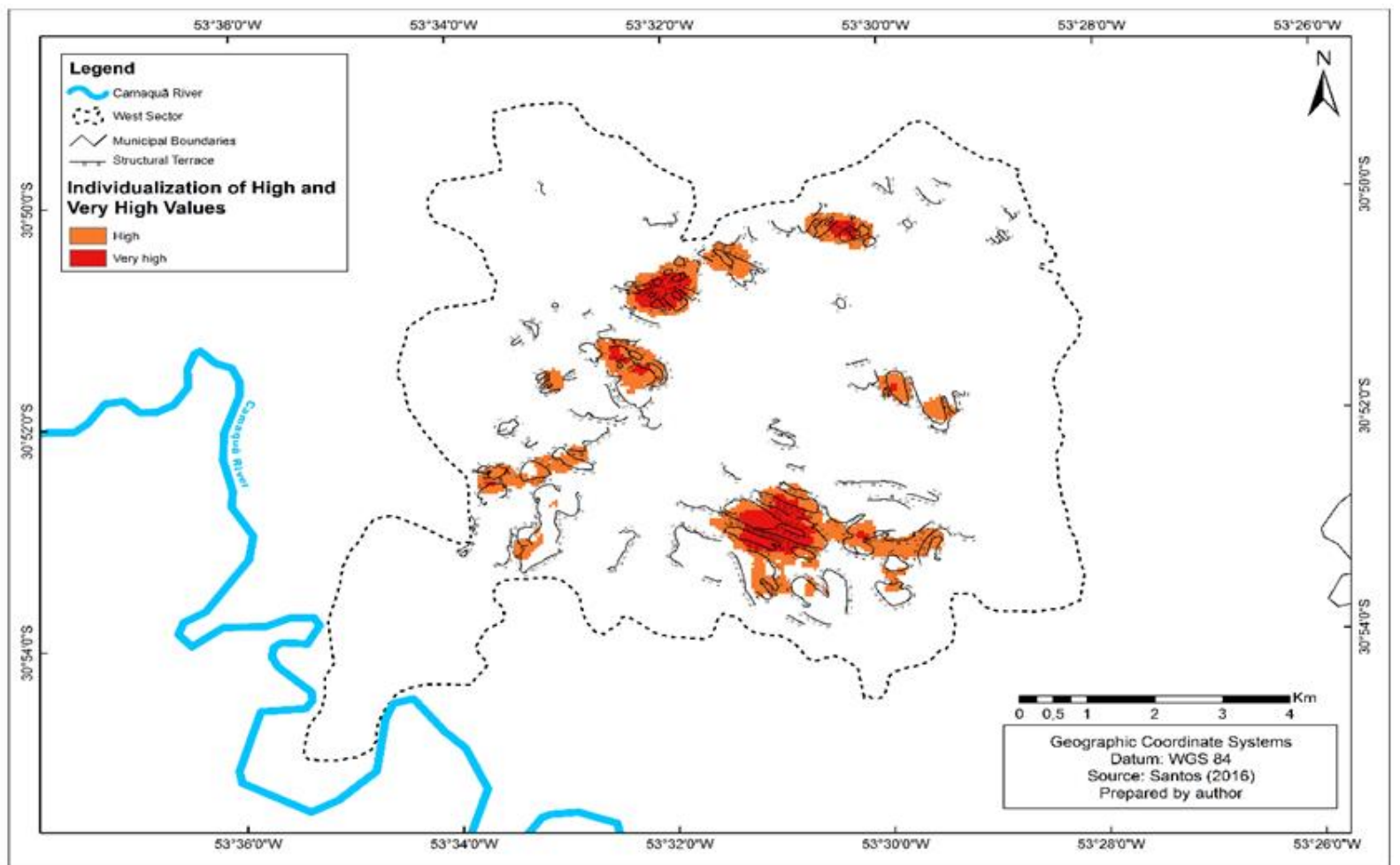

Figure 5. Results of the individualization of the areas with high and very high spatial concentration values of structural terraces in the west sector of Guaritas do Camaquã geomorphosite. The same procedure was used for all the other features.

The high and very high spatial concentrations were classified again and the value of " 1 " was attributed to them. The other spatial concentrations (null, very low, low and medium) received the value " 0 " (Figure 6).

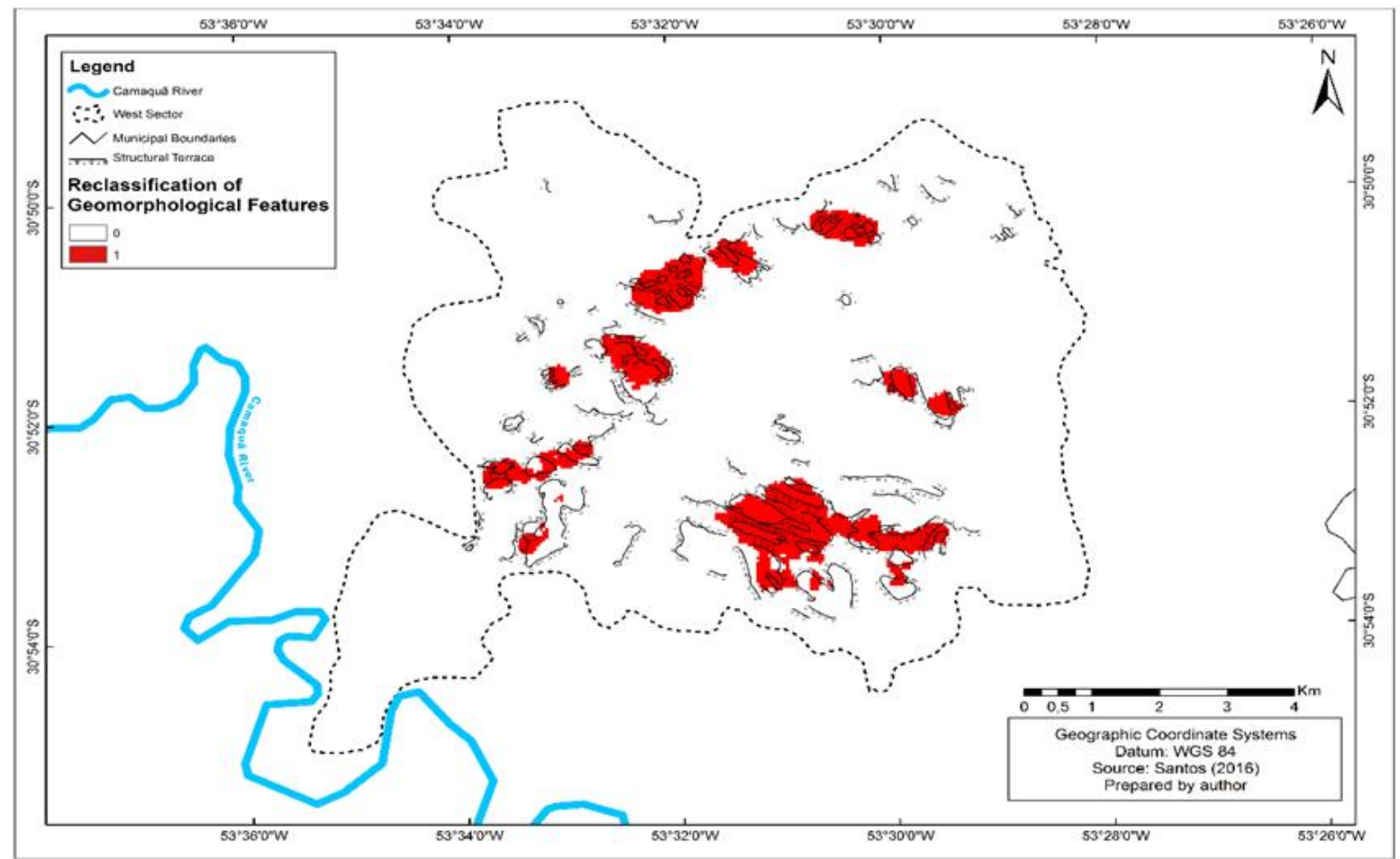

Figure 6. Distribution of the high and very high values of the spatial concentration areas of structural terraces in the west sector of Guaritas do Camaquã geomorphosite. The same procedure was used for all the other features. 
2.2.3 Obtaining the map of the spatial concentration of the geomorphological heritage elements

The map of the spatial concentration of the geomorphological heritage elements for each of the analysis sectors were obtained using map algebra data model (ESRI, 2013) produced with the high and very high spatial concentration of the geomorphological features (Figure 7). The overlap of the values high and very high allowed the identification of the areas with higher geotouristic potential in the geomorphosite.

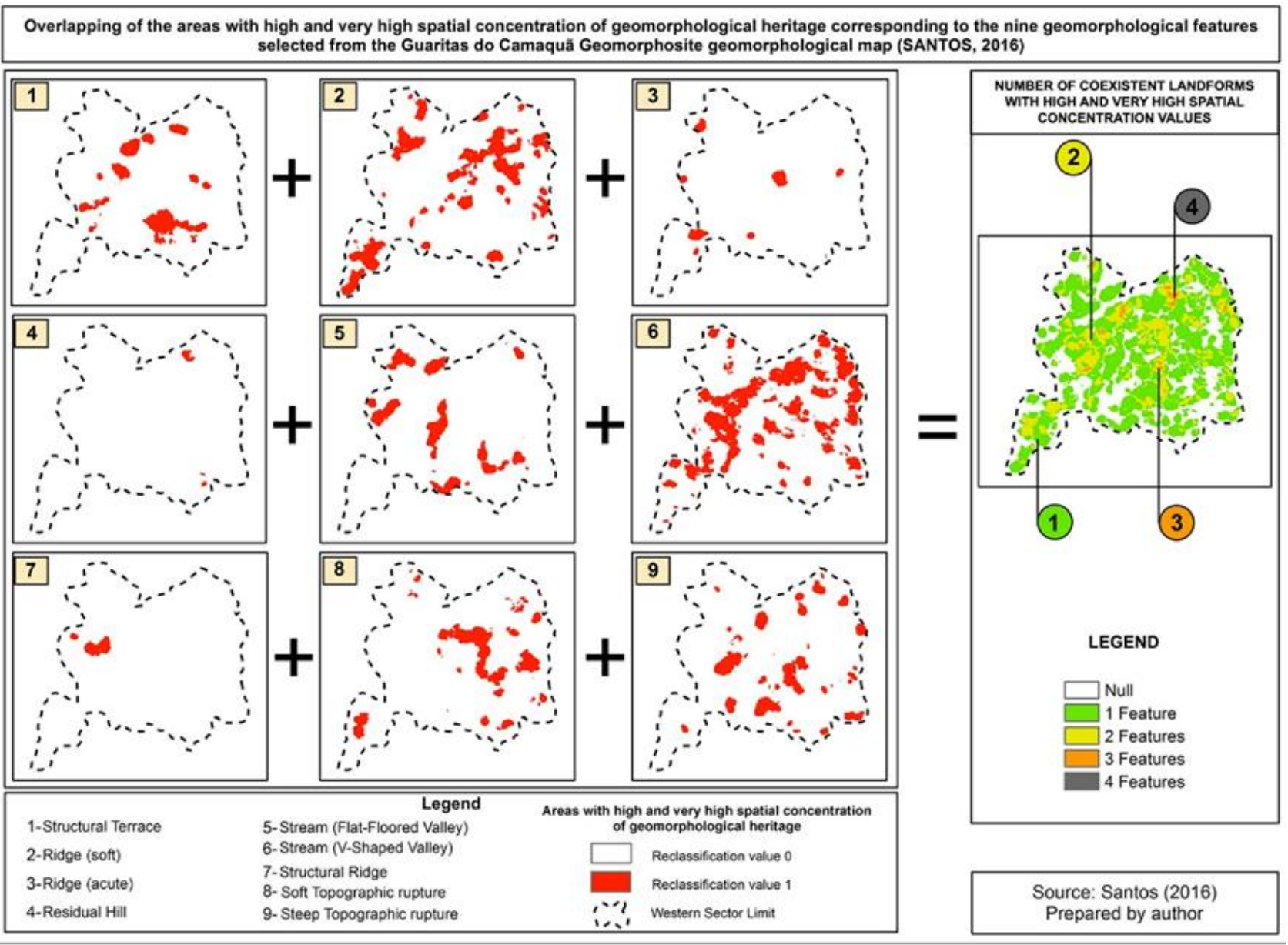

Figure 7. On the left: map algebra of the high and very high spatial concentration values of nine of the selected geomorphological features (example from the west sector of Guaritas do Camaquã geomorphosite). On the right: results from the map algebra allowing the verification of the coexistence of, in the maximum, four geomorphological features with high and very high spatial concentration values.

Finally, fieldtrips helped in the recognition and in obtaining photographic registers of the areas with high spatial concentration of landforms.

\section{Results}

Geomorphological features with high and very high spatial concentration occupy $63.03 \%$ of the west sector, $46.27 \%$ of the central sector and $59.42 \%$ of the east sector. The coexistence of high and very high spatial concentration of the geomorphological features indicates the probability of the occurrence of a composition of landforms with geotouristic potential. Next, we will present the analysis of the spatial concentration of the geomorphological heritage elements in the three sectors under study here.

\subsection{West Sector}

In the West sector, the geomorphological features with the highest spatial concentrations (high and very high) were: streams in V-shaped valleys $\left(18.42 \mathrm{~km}^{2}\right)$; soft ridges $\left(12.71 \mathrm{~km}^{2}\right)$; and steep topographic ruptures $(7.38$ 
$\mathrm{km}^{2}$ ) (Figure 8). These findings show that fluvial and denudation landforms are predominant in the definition of the geomorphological heritage elements with high spatial concentrations in this sector.

\section{Areas with high and very high spatial concentration of geomorphological features}
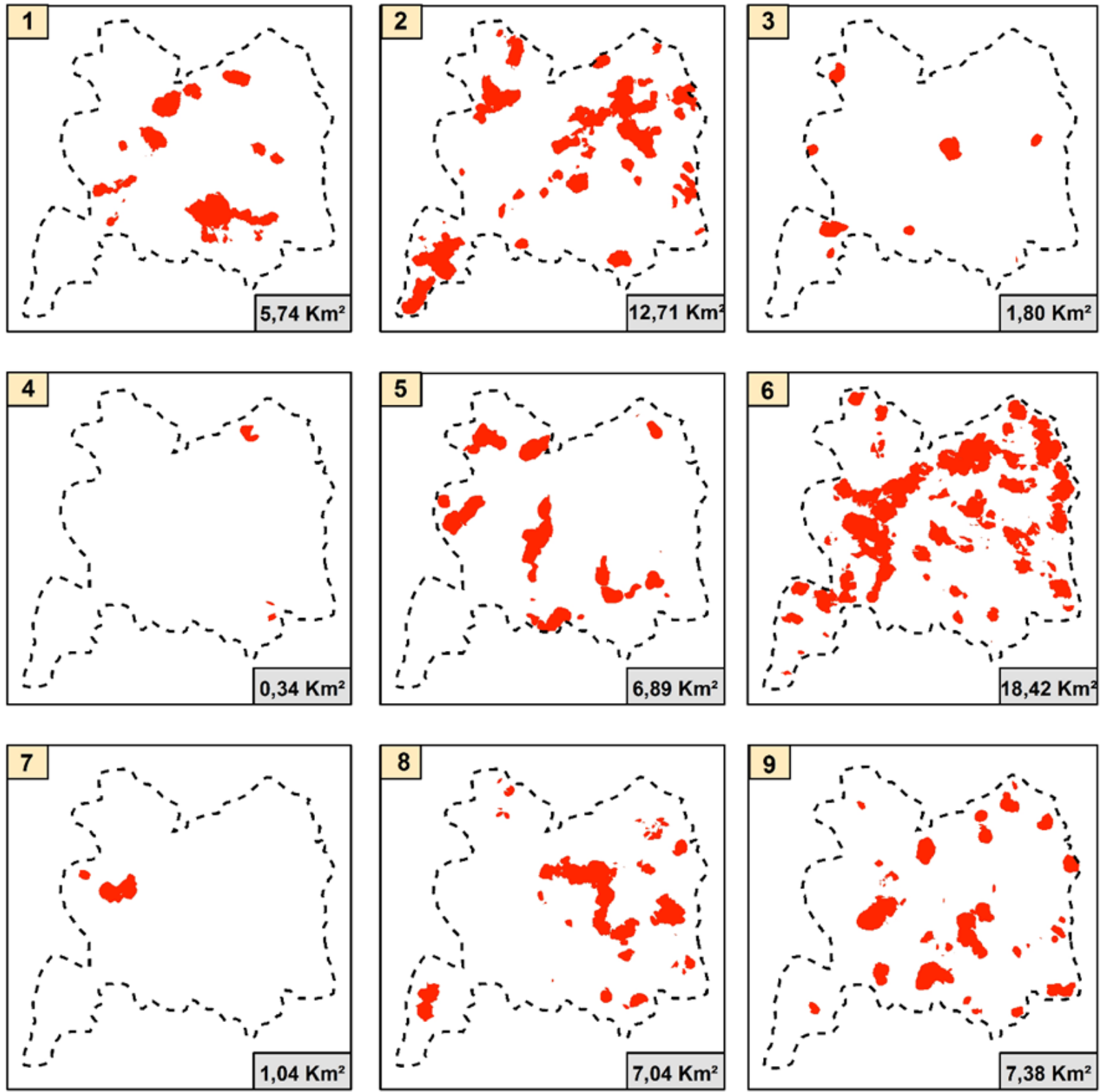

\begin{tabular}{|ll|c}
\hline & \multicolumn{1}{c}{ Legend } \\
1-Structural Terrace & 5-Stream (Flat-Floored Valley) & \\
2-Ridge (soft) & 6-Stream (V-Shaped Valley) & Reclassification value 0 \\
3-Ridge (acute) & 7-Structural Ridge & Reclassification value 1 \\
4-Residual Hill & 8-Soft Topographic rupture & 9-Steep Topographic rupture \\
\hline
\end{tabular}

Figure 8. Coverage areas of the high and very high spatial concentrations of the geomorphological features of the west sector of Guaritas do Camaquã geomorphosite. 
Other geomorphological features with a relevant role in the definition of the sets of geomorphological heritage elements are more isolate in the West sector and have smaller areas of distribution of high and very high spatial concentrations. These features are: structural terraces $\left(5.74 \mathrm{~km}^{2}\right)$; structural ridges $\left(1.04 \mathrm{~km}^{2}\right)$; and residual hills $\left(0.34 \mathrm{~km}^{2}\right)$ (Figure 8$)$. The high and very high spatial concentrations of these features are predominant on surfaces with significant altimetry amplitude (180 to 300 meters - Figure 1). This situation contributes to the occurrence of rocky cliffs and slope ruptures, exposing rocky outcrops and layers of the different alloformations in the geomorphosite.

The overlap of the high and very high spatial concentrations of the geomorphological features revealed the co-existence of up to 4 morphologies in an isolated cut of the west sector (Figure 9). The Pedra das Guaritas is located in this cut and it is one of the most relevant geomorphological heritage elements in the Guaritas do Camaquã geomorphosite (Figure 10). The Pedra das Guaritas has been used for fieldtrips and scientific studies, as it shows aspects of the conglomerates of Varzinha Alloformation. This geomorphological heritage element is also representative of the residual features developed by the action of different paleoclimate and the actual morphoclimate conditions.

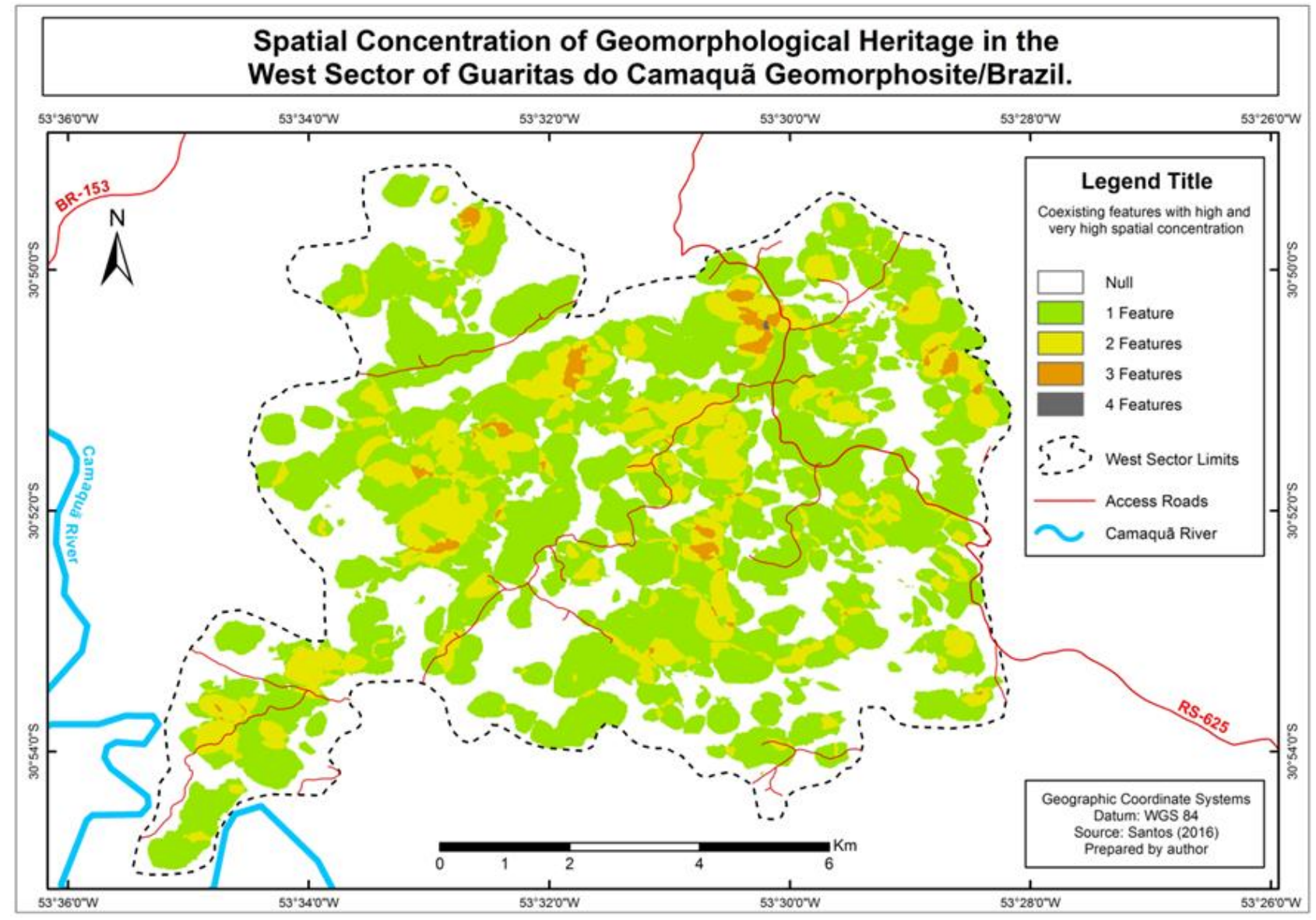

Figure 9. Map of the high and very high spatial concentrations of the geomorphological heritage elements from the West sector of the Guaritas do Camaquã geomorphosite. 


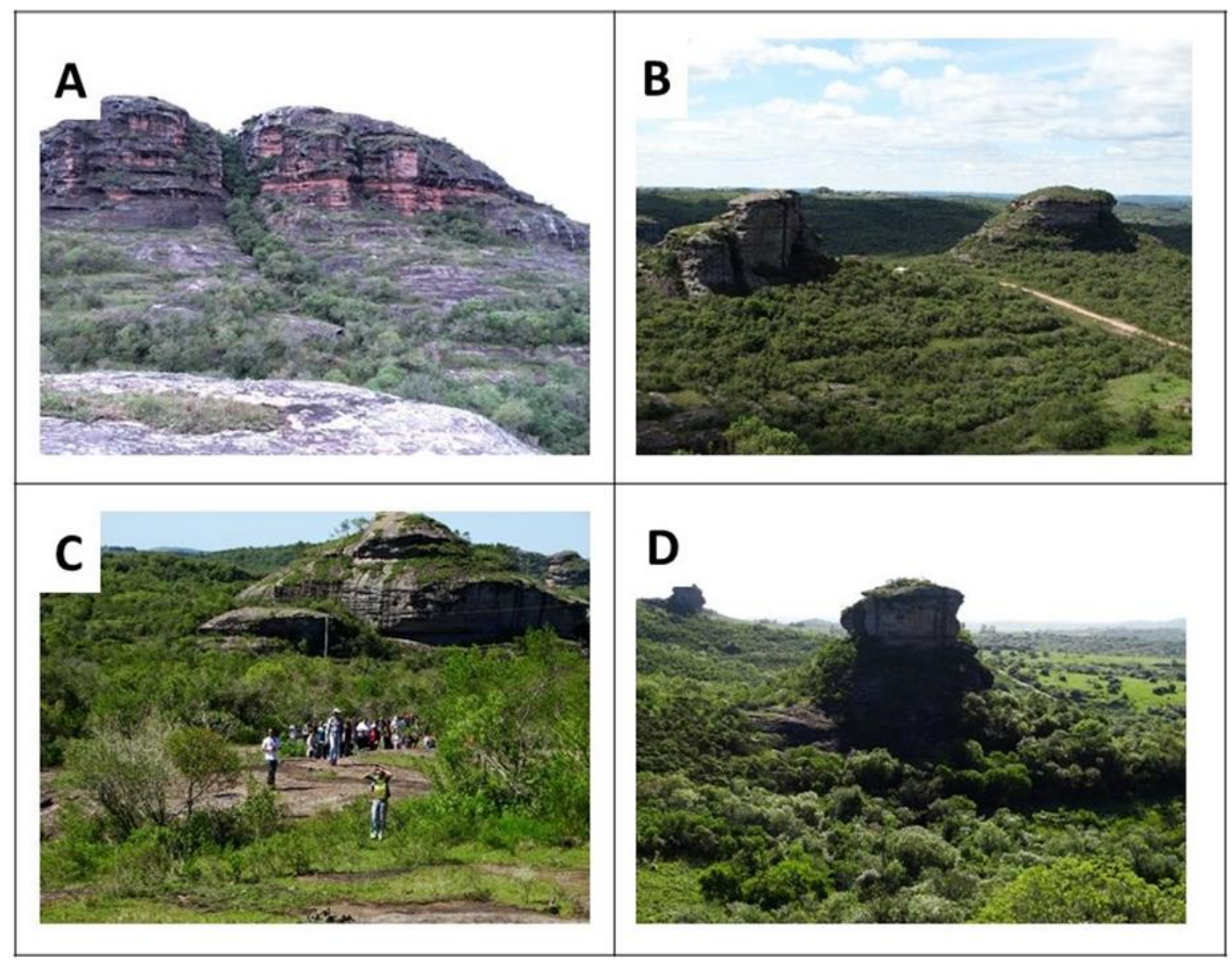

Figure 10. (A) View of Pedra das Guaritas; (B) View from the upper portion of Pedra das Guaritas; (C) Track trails in the geodiversity day (Geo.Dia); (D) Residual hills around Pedra das Guaritas. Source: The authors.

The areas with high spatial concentration of geomorphological heritage elements in the west sector of the geomorphosite are mainly located near to the main and secondary roads (Figure 9). This is relevant as it influences further propositions of geotouristic itineraries, which will involve the other geomorphological heritage elements in this sector, strengthening the participation of this geomorphosite in the proposal of Caçapava do Sul Geopark.

\subsection{Central Sector}

The central sector of the Guaritas do Camaquã geomorphosite is located at the lower valley bottom of João Dias stream (Figure 1), which is one of the main regional level base of the CSB. The morphodynamic processes in this sector contributed to the segmentation and isolation, in an advanced stage, of the ruiniform features. Therefore, the landforms are more monotonous and the geomorphological heritage elements are less attractive for geotourism.

In the central sector, the V-shaped valleys $\left(9.39 \mathrm{~km}^{2}\right)$, the smooth ridgelines $\left(3.04 \mathrm{~km}^{2}\right)$ and the steep topographic ruptures $\left(3.97 \mathrm{~km}^{2}\right)$ are the geomorphological features with the highest spatial concentrations (Figure $11)$. 


\section{Areas with high and very high spatial concentration of geomorphological features}
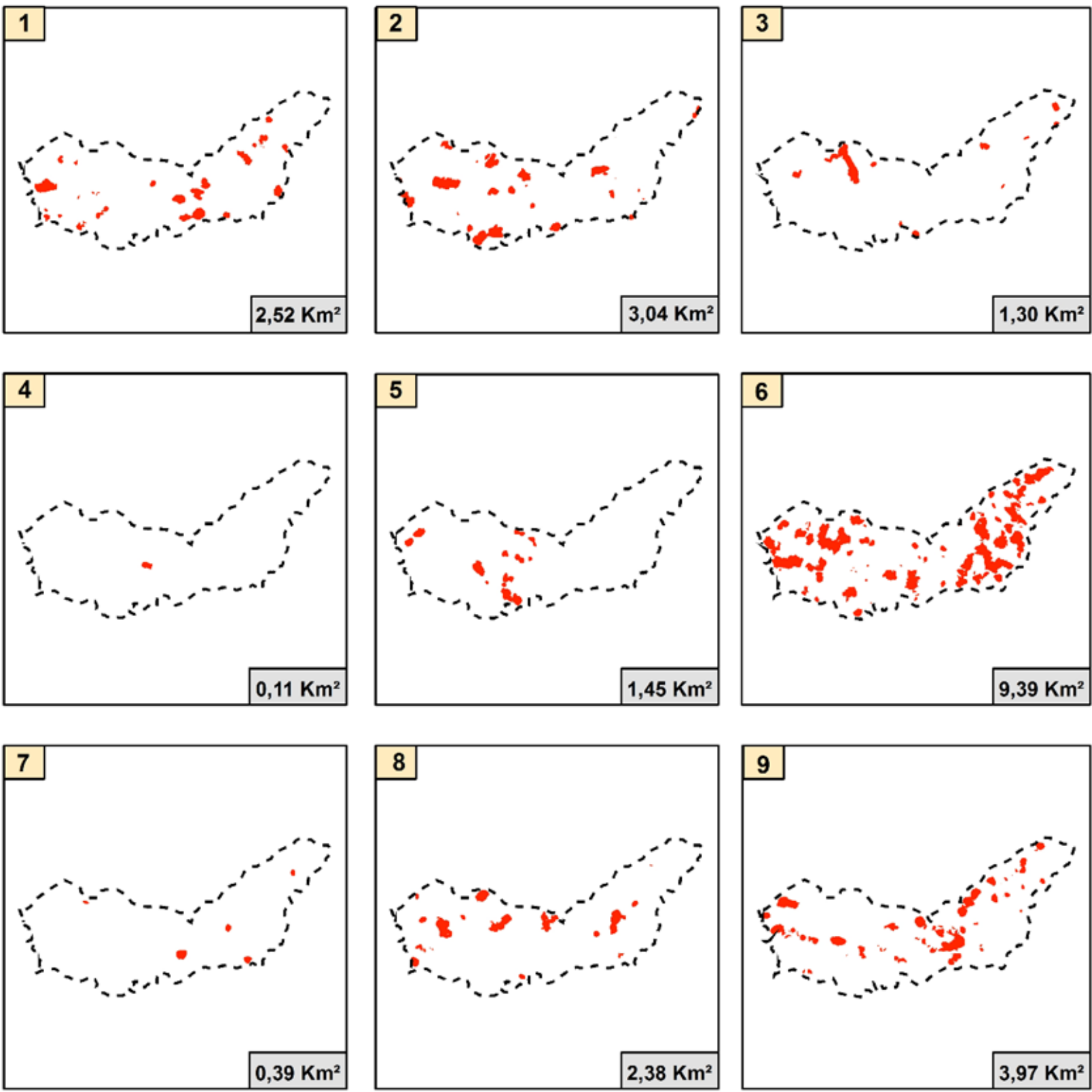

\begin{tabular}{|ll|l|}
\hline & \multicolumn{1}{c|}{ Legend } \\
1-Structural Terrace & 5-Stream (Flat-Floored Valley) & \multicolumn{1}{c}{ Reclassification value 0 } \\
2-Ridge (soft) & 6-Stream (V-Shaped Valley) & Reclassification value 1 \\
3-Ridge (acute) & 7-Structural Ridge & 8-Soft Topographic rupture \\
4-Residual Hill & 9-Steep Topographic rupture & Western Sector Limit \\
\hline
\end{tabular}

Figure 11. The high and very high spatial concentrations of the geomorphological features of the central sector of the Guaritas do Camaquã geomorphosite. Source: The authors.

The co-existence of areas of high and very high spatial concentration of these geomorphological features occur in discontinued and isolated areas in this sector, and it includes the maximum of three geomorphological features. 
The overlap of the maps from the areas of high and very high concentrations of geomorphological features in the central sector allowed the identification of a low association capacity of the landforms in the organization of geomorphological heritage elements with aesthetic attractiveness. The prevalence of areas with high and very high occurrence values for only one geomorphological feature explains this situation (Figure 12 - in green).

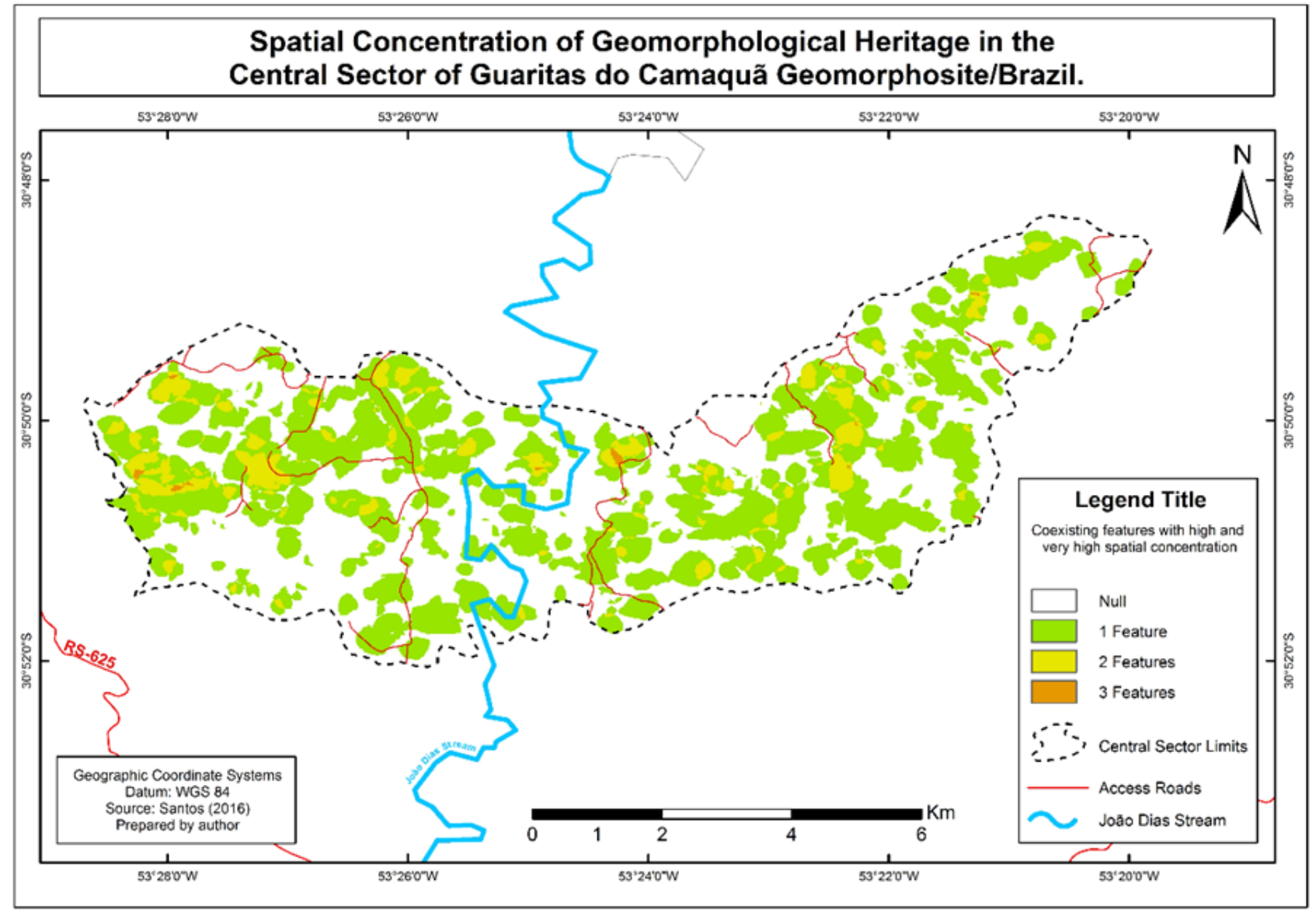

Figure 12. Map of the high and very high concentrations of geomorphological features in the central sector of the Guaritas do Camaquã geomorphosite. Source: Authors.

Although unimpressive regarding the spatial association of the landforms, there are potential geomorphological heritage elements for geotourism. However, these have not been well advertised due to their isolation, which hampers the insertion of the already restricted geomorphological heritage elements of this sector in geotouristic guides.

Such geomorphological heritage elements have designated and recognized toponymies that are recognized mainly by the local inhabitants and are situated in areas difficult to reach. Therefore, the areas with the largest spatial concentrations of landforms in this sector (Figure 13) should be the target of future actions that will allow them to be accessed and used for geotourism. 


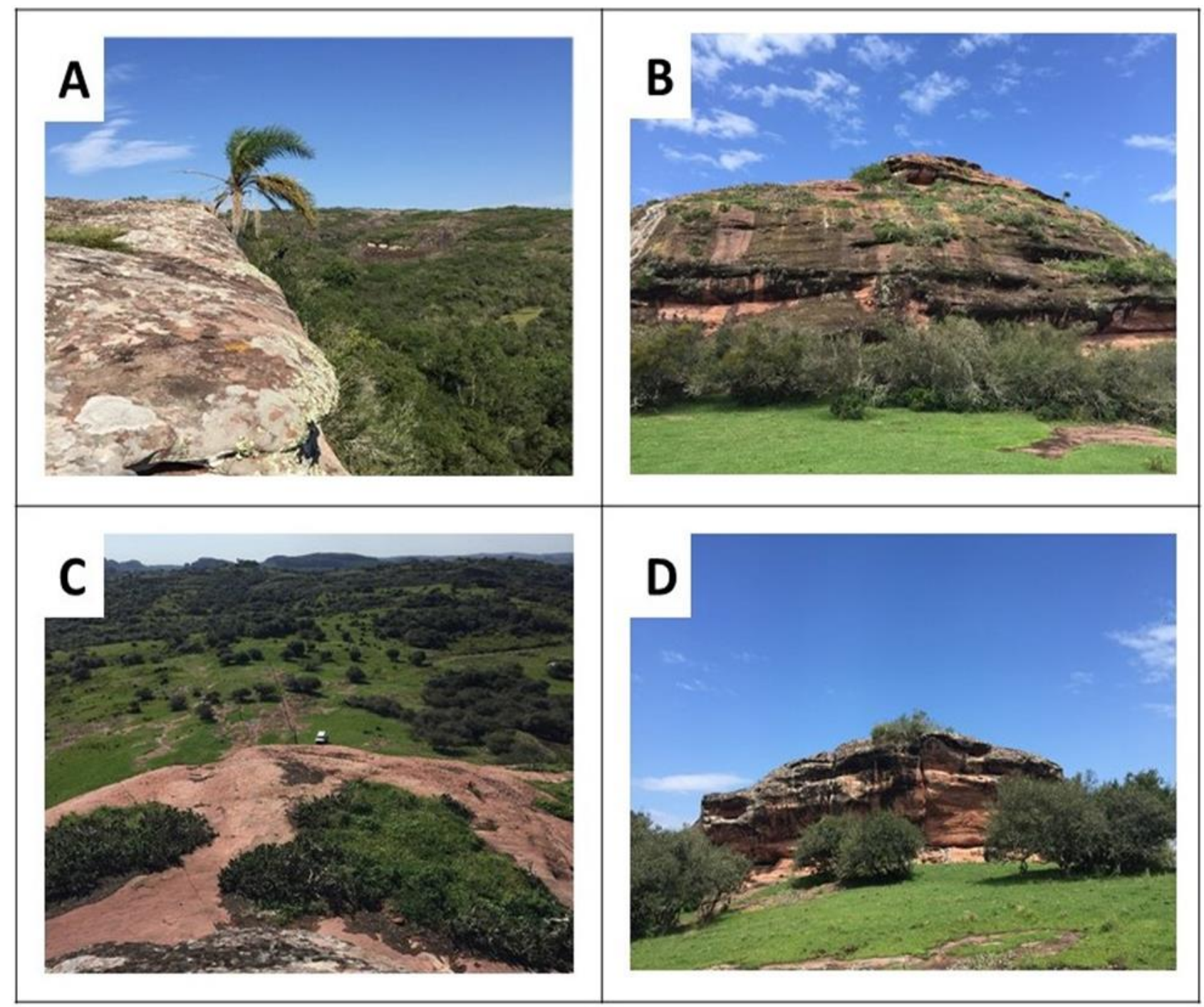

Figure 13. (A and C) General view from the upper part of the structural terraces in the central sector; (B and D) Ruiniform features located in the central-north portion of the central sector, an isolated area. The structural terraces are ideal places for climbing and for trails (medium to high difficulty). Source: Authors.

\subsection{East Sector}

The east sector comprises the largest topographic ranges of the Guaritas do Camaquã geomorphosite. The higher elevations reach 355 meters, and some valley bottoms are located at a topographic level of 130 meters of altitude (Figure 1). Such topographic configuration allows the predominance of areas with high and very high values of spatial concentration of V-shaped streams $\left(21.96 \mathrm{~km}^{2}\right)$, structural terraces $\left(13.76 \mathrm{~km}^{2}\right)$, soft ridges $(12.48$ $\left.\mathrm{km}^{2}\right)$ and steep topographic ruptures $\left(10,33 \mathrm{~km}^{2}\right)$ (Figure 14).

These characteristics are an indication of fluvial and pluvial processes, in significant topographic ranges, acting on the vertical incision of the landforms, producing residual features under strong structural control (contact between Varzinha and Pedra Pintada Alloformations), which tend to the organization of highlighted geomorphological heritage elements in the landscape. 


\section{Areas with high and very high spatial concentration of geomorphological features}
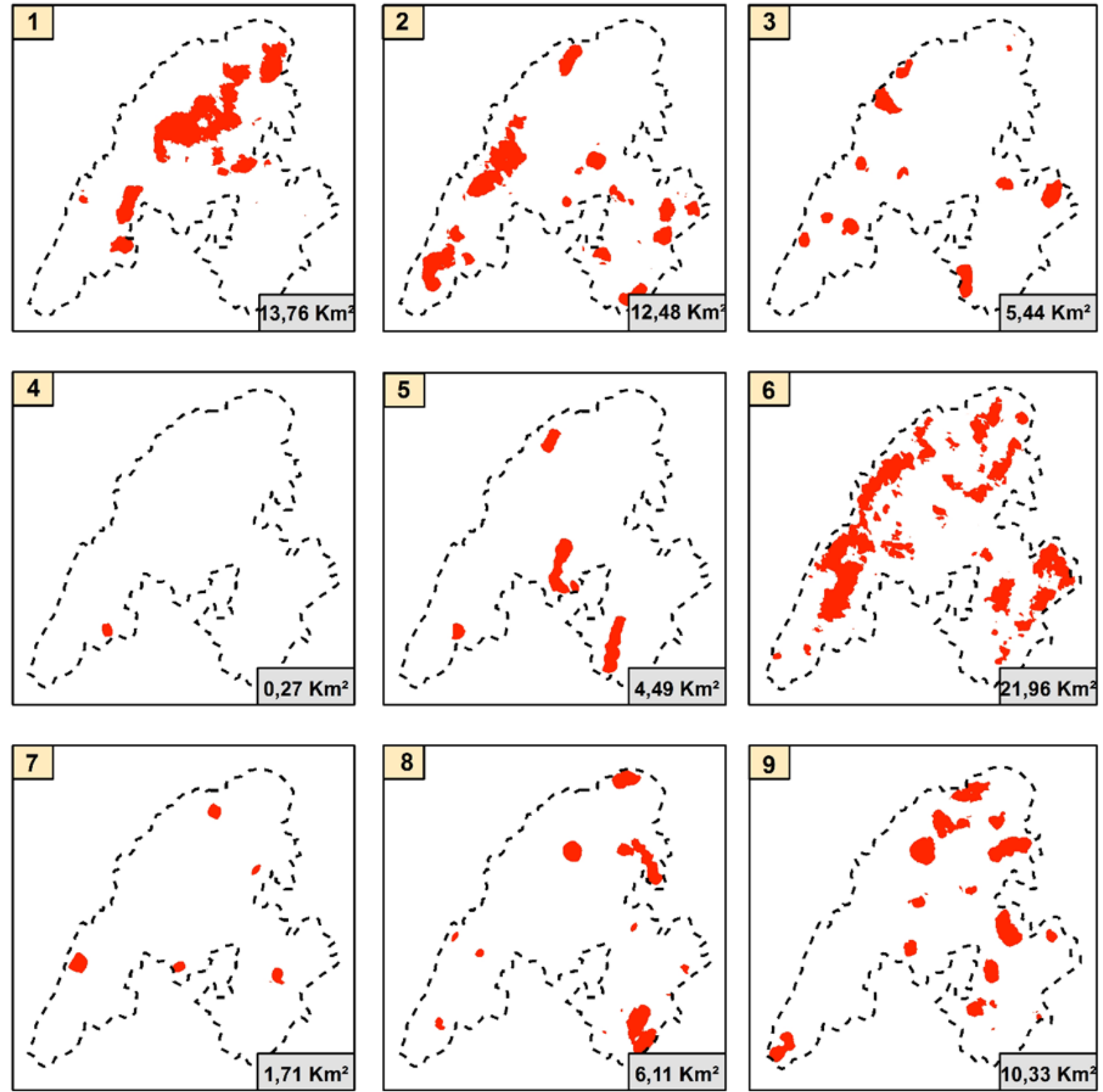

\begin{tabular}{|c|c|c|}
\hline \multicolumn{3}{|c|}{ Legend } \\
\hline 1-Structural Terrace & 5-Stream (Flat-Floored Valley) & \\
\hline 2-Ridge (soft) & 6-Stream (V-Shaped Valley) & Reclassification value 0 \\
\hline 3-Ridge (acute) & $\begin{array}{l}\text { 7-Structural Ridge } \\
\text { 8-Soft Topographic rupture }\end{array}$ & Reclassification value 1 \\
\hline 4-Residual Hill & 9-Steep Topographic rupture & Western Sector Limit \\
\hline
\end{tabular}

Figure 14. High and very high spatial concentration of the geomorphological features in the east sector of Guaritas do Camaquã geomorphosite. Source: Authors.

The overlap of the maps from the areas of high and very high spatial concentration of the geomorphological features revealed the co-existence of a maximum of 3 morphologies with high spatial concentration. Such concentration occupies representative areas of the east sector, giving support to the occurrence of a diversity of geomorphological heritage elements (Figure 15) 


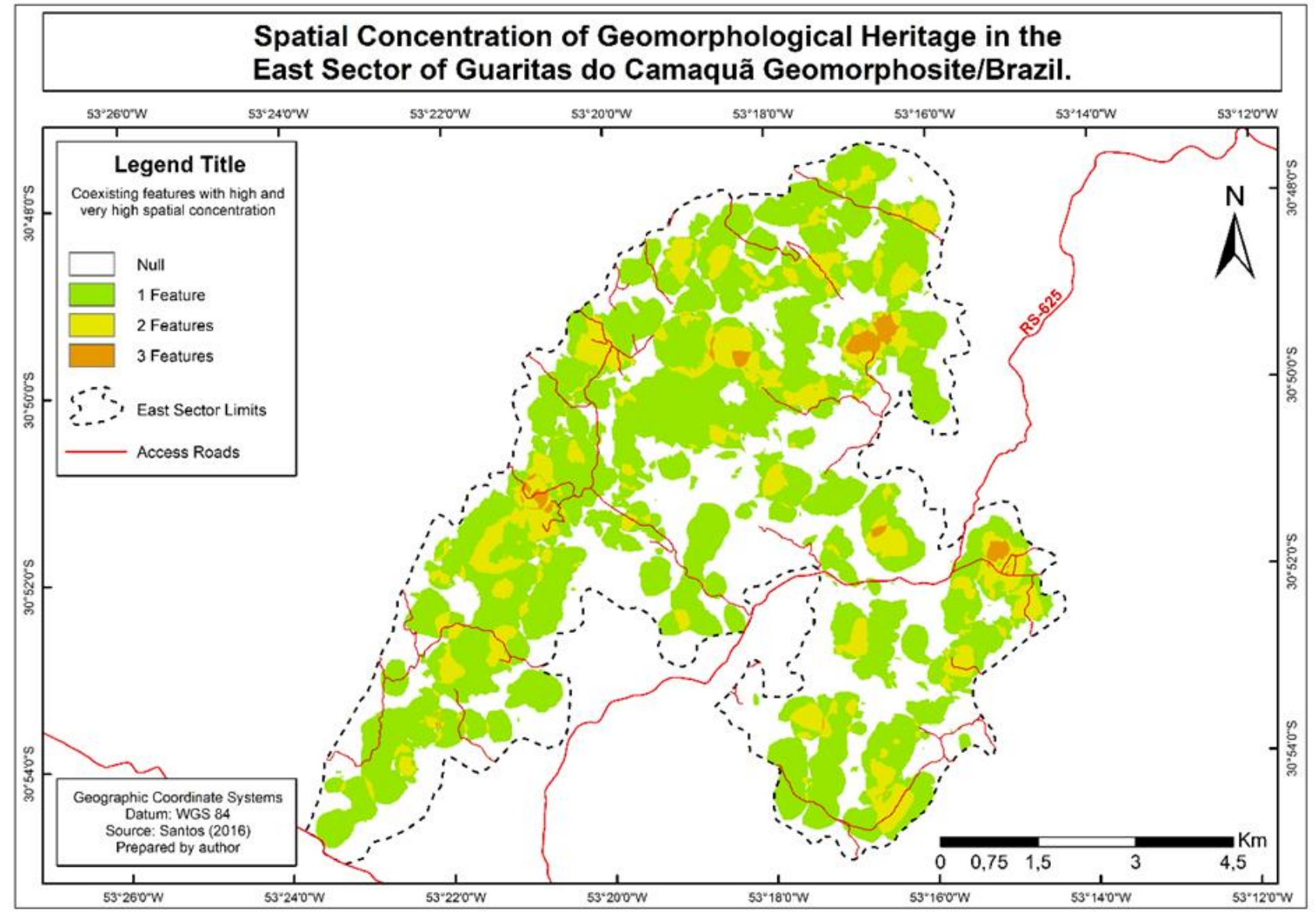

Figure 15. Map of the high and very high spatial concentration of the geomorphological heritage elements in the east sector of Guaritas do Camaquã geomorphosite. Source: Authors.

The main and secondary roads in the east sector lead to the areas where there are high spatial concentrations of geomorphological heritage elements (Figure 16). This is an important aspect to be considered if we think about the dissemination of geotourism practices, and the consolidation of tourist routes that would include the rural properties where the high spatial concentration of landforms is located.

Despite having many areas with a high spatial concentration of geomorphological heritage elements, these places have not been well used for either tourist or pedagogic-scientific purposes. One of the reasons for that is that this sector is located in Santana da Boa Vista municipality, where not enough attention has been given to the consolidation of a geopark in the area. 


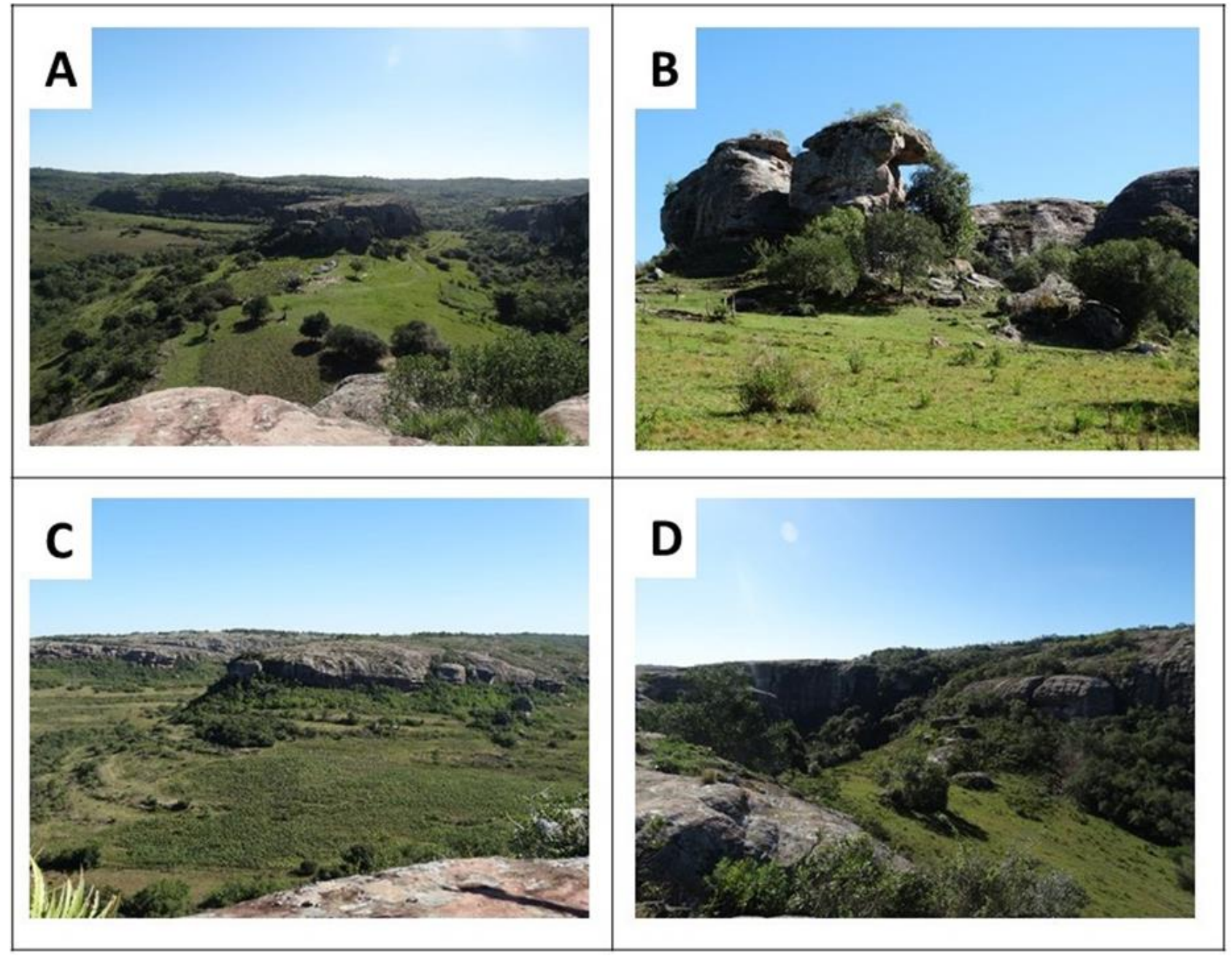

Figure 16. (A) View from the upper part of the residual hill in an area where three geomorphological features with high spatial concentrations values coexist. A rural property is associated to the landscape; (B) Rocky outcrops associated to the residual hills; (C and D) Rocky cliffs delimiting steep topographical ruptures and structural terraces in the west sector. Source: Authors.

The East sector presents the largest exhibitions of rocky outcrops on the top compartments with affordable access. Such configuration allows the establishment of walking trails that would benefit the view provided by the geomorphosite, the geomorphological heritage elements and other elements from the surrounding landscape. These touristic practices should be articulated with the rural properties that will act as a "reception desk" to the geotourists.

\section{Conclusion}

The methodology used in this study could identify and validate the occurrence of the main geomorphological heritage elements of the Guaritas do Camaquã geomorphosite. The spatial analysis of data presented in the geomorphological map produced by Santos (2016) allowed a more detailed view of the set of landforms that comprise the geomorphological heritage elements of the geomorphosite. Such information should guide future propositions regarding geotouristic routes and geoconservation actions.

Despite revealing areas that have been already used for pedagogical-scientific, touristic and economic purposes, the maps of spatial concentration of the geomorphological heritage elements have also revealed isolated sets of landforms that are poorly explored and unknown. Such sets of landforms need to be incorporated to the geotouristic routes of the geomorphosite.

The west sector is the only area that has the coexistence of four features of landforms with high spatial concentrations, making this sector the most representative to the development of geotouristic, 
pedagogical-scientific and economical activities. However, others than Pedra das Guaritas geomorphological heritage element must be incorporated to the geotouristic routes, using the existent roads.

The central sector shows the smallest associations between the landforms with the high spatial concentrations. This is due to the evolution of the relief in the area (highly dissected surfaces, with a low topographic range, located in the central area of a sedimentary basin) that results in the organization of isolated sets of landforms, with low geotouristic appeal. These areas can be incorporated to the geotouristic routes, as they have a pedagogical-scientific relevance in explaining the genesis and evolution of the landforms in a sedimentary basin.

The east sector presents the most homogeneous distribution of the areas where geomorphological features with high spatial concentrations coexist. It also displays the highest number of roads to these areas. However, this sector also poses the biggest challenges to the promotion of the geomorphological heritage elements, as the roads are not well kept, which practically isolates the rural properties in this sector.

We recommend monitoring the areas where the main geomorphological heritage elements are located (land-cover and land-use monitoring), as a way of evaluating the impact of the occupation on the landforms and processes that comprise this geomorphological heritage.

It is important to highlight that this analysis was only possible due to the existence of a geomorphological map of the area, with emphasis on morphography. Therefore, it is important that such elementary documents continue being produced to facilitate the initial characterization of the landforms in geomorphosites and geosites.

Contribuições dos Autores: Concepção: Márlon Roxo Madeira e Adriano Luís Heck Simon; metodologia, Márlon Roxo madeira, Adriano Luís Heck Simon e Edvania Aparecida Correa Alves; software: Adriano Luís Heck Simon; validação, Márlon Roxo Madeira, Adriano Luís Heck Simon; análise formal: Márlon Roxo Madeira; pesquisa: Márlon Roxo Madeira; recursos: Adriano Luís Heck Simon; preparação de dados: Márlon Roxo Madeira; escrita do artigo: Márlon Roxo Madeira, Adriano Luís Heck Simon e Edvania Aparecida Correa Alves; revisão: Adriano Luís Heck Simon e Edvania Aparecida Correa Alves; supervisão: Adriano Luís Heck Simon; aquisição de financiamento: Adriano Luís Heck Simon. Todos os autores leram e concordaram com a versão publicada do manuscrito.

Financiamento: Esta pesquisa foi financiada pelo Conselho Nacional de Desenvolvimento Científico e Tecnológico (CNPq), número do processo 408218/2013-4.

Agradecimentos: Os autores agradecem a Universidade Federal de Pelotas (UFPel) e a Universidade Federal de Santa Maria (UFSM) pelo apoio institucional durante o desenvolvimento desse trabalho.

Conflito de Interesse: Os autores declaram não haver conflito de interesse.

\section{Referências}

1. BORBA, A. W. Geodiversidade e geopatrimônio como bases para estratégias de geoconservação: conceitos, abordagens, métodos de avaliação e aplicabilidade no contexto do Estado do Rio Grande do Sul. Pesquisa em Geociências, v. 38, n. 1, p. 3-14, 2011, 2011. DOI: 10.22456/1807-9806.23832

2. BURROUGH, P. A. Principles of Geographic Information Systems for Land Resources Assessment. Oxford: Oxford University Press, 1986.

3. CÂMARA, G.; MONTEIRO, A. M.; FUCKS, S. D.; CARVALHO, M. S. Análise espacial e geoprocessamento. In: DRUCK, S.; CARVAlHO, M.S.; CÂMARA, G.; MONTEIRO, A.V.M. (Eds.) Análise Espacial de Dados Geográficos. $1^{\text {a }}$ Ed. Brasília: EMBRAPA, 2004. Disponível em: <http://www.dpi.inpe.br/gilberto/livro/analise/>. Acesso em: 27/11/2018.

4. CARTON, A.; CORATZA, P.; MARCHETTI, M. Propositions pour la cartographie des sites géomorphologiques: exemples italiens. Revue du Groupe Français de Géomorphologie, n. 3, p. 209-218, 2005.

5. CHEMALE JR. F. Evolução Geológica do Escudo Sul-riograndense. In: HOLZ, M.; ROS, L. F. (Eds) Geologia do Rio Grande do Sul. 1ª Ed. Porto Alegre: CIGO/UFRGS, p. 13-52, 2000.

6. CORATZA, P.; HOBLÉA, F. The Specificities of Geomorphological Heritage. In: REYNARD, E. BRILHA, J. Geoheritage: Assessment, Protection, and Management. Elsevier: Amsterdam. p. 87-106, $2018 . \quad$ DOI: 10.1016/b978-0-12-809531-7.00005-8.

7. CUNHA, C. M. L. A cartografia do relevo no contexto da gestão ambiental. Tese (Doutorado em Geociências e Meio Ambiente) - Instituto de Geociências e Ciências Exatas, Universidade Estadual Paulista, Rio Claro, 2001. 128p.

8. CUNHA, C. M. L.; MENDES, I. A.; SANCHEZ, M. C. A cartografia do relevo: uma análise comparativa de técnicas para a gestão ambiental. Revista Brasileira de Geomorfologia. v. 4, n. 1, p. 1-9, 2003. DOI: 10.20502/rbg.v4i1.15 
9. CUNHA, L.; VIEIRA, A. Património geomorfológico, recurso para o desenvolvimento local em espaços de montanha. Exemplos de Portugal Central. Cadernos de Geografia, n. 21/23, p. 15-28, 2004. Disponível em: $<$ http://hdl.handle.net/1822/13792>. Acesso em: 02/02/2018.

10. ESRI. ArcGIS 10.2.1 for Desktop. Redlands: ESRI, 2013. Cópia digital.

11. FIGUEIRÓ, A. S.; VIEIRA, A.; CUNHA, L. Patrimônio geomorfológico e paisagem como base para o geoturismo e o desenvolvimento local sustentável. CLIMEP - Climatologia e Estudos da Paisagem, v. 8, n. 1, p. 49-81, 2013.

12. GRAY, M.; GORDON, J. E.; BROWN, E. J. Geodiversity and the ecosystem approach: the contribution of geoscience in delivering integrated environmental management. Proc. Geol. Assoc. v. 124, n. 4, p. 659-673, 2013. DOI: 10.1016/j.pgeola.2013.01.003.

13. MARASCHIN, A. J.; MIZUSAKI, A. M.; ZWINGMANN, H.; BORBA, A. W.; SBRISSA, G. F. Illite authigenesis in sandstones of the Guaritas Allogroup (Early Paleozoic): Implications for the depositional age, stratigraphy and evolution of the Camaquã Basin (Southern Brazil). Journal of South American Earth Sciences, v. 29, n. 2, p. 400-411, 2010. DOI: 10.1016/j.jsames.2009.07.007

14. MEDEIROS, A. M. L. Artigos sobre Conceitos em Geoprocessamento. E-book, 2012. 32p. Disponível em: $<$ http://www.clickgeo.com.br/wp-content/uploads/2012/09/E-book-Artigos-sobre-Conceitos-em-Geoprocessamento-And erson-Medeiros.pdf >. Acesso em: 30/03/2019.

15. MEDEIROS, J. S.; CÂMARA, G. Geoprocessamento em Projetos Ambientais. Tutorial Apresentado no Congresso GIS Brasil, 1998. Disponível em: <http://www.dpi.inpe.br/gilberto/tutoriais/gis_ambiente/>. Acesso em: 27/10/2018

16. MELELLI, L.; VERGARI, F.; LIUCCI, L.; DEL MONTEB, M. Geomorphodiversity index: Quantifying the diversity of landforms and physical landscape. Science of the Total Environment, v. 584-585, p. 701-714, 2017. DOI: 10.1016/j.scitotenv.2017.01.101.

17. PAIM, P. S. G.; FALlGATTER, C.; SILVEIRA, A. S. Guaritas do Camaquã, RS - Exuberante cenário com formações geológicas de grande interesse didático e turístico. In: WINGE, M.; SCHOBBENHAUS, C.; SOUZA. C. R. G.; FERNANDES, A. C. S.; BERBERT-BORN, M.; SALLUNU FILHO, W.; QUEIROZ, E. T. (Org.). Sítios Geológicos e Paleontológicos do Brasil. 1 ${ }^{a}$ Ed. Brasília: Departamento nacional de Produção Mineral, 2010. p. 1-13.

18. PAIM, P. S. G.; LOPES, R. C. Geologia da Região das Minas do Camaquã. In: RONCHI, L. H.; LOBATO, A. O. C. (Org.) Minas do Camaquã, um Estudo Multidisciplinar. 1ª Ed. São Leopoldo: UNISSINOS, 2000. p. 111-132.

19. PAIM, P. S. G.; SCHERER, C. M. S. High Resolution Stratigraphy and Depositional Model of Wind-and-Water-Laid Deposits in the Ordovician Guaritas Rift (southernmost Brazil). Sedimentary Geolology, v. 202, n 4, 2007 , p. 776-795. DOI: 10.1016/j.sedgeo.2007.09.003

20. PANIZZA, M. Geomorphosites: Concepts, Methods and Examples of Geomorphological Survey. Chinese Science Bulletin, v. 46, p. 4-6, 2001. DOI: 10.1007/BF03187227

21. PEREIRA, J. G. Contribuição ao Estudo Geológico da Bacia do Camaquã - RS, Através de Modelagem Aeromagnética 2,5D. 2011. Dissertação (Mestrado em Sensoriamento Remoto) - Universidade de Brasília, 2011. 142p.

22. REYNARD, E. Geomorphosites: definition and characteristics. In: REYNARD, E.; CORATZA, P.; REGOLINI-BISSIG, G. (Eds.), Geomorphosites. $1^{\text {a }}$ Ed. Verlag Dr. Friedrich Pfeil: München, p. 9-20, 2009.

23. REYNARD, E.; CORATZA, P. The importance of mountain geomorphosites for environmental education. Examples from the Italian Dolomites and the Swiss Alps. Acta geogr. Slov. v. 56, n. 2, p. 291-303, 2016. DOI: 10.3986/1684.

24. RIO GRANDE DO SUL. Secretaria de Coordenação e Planejamento. Atlas Socioeconômico do Rio Grande do Sul. Porto Alegre: Edição Eletrônica, 2003. Disponível em: <http://www.scp.rs.gov.br/atlas/default.asp>. Acesso em: 05/03/2018.

25. RODRIGUES, M. L.; FONSECA, A. Geoheritage assessment based on large-scale geomorphological mapping: contributes from a Portuguese limestone massif example. Géomorphologie: relief, processus, environnement, v. 16, n. 2, p. 189-198, 2010. DOI: $10.4000 /$ geomorphologie.7924

26. SANTOS, D.S.; REYNARD, E.; MANSUR, K.L.; SEOANE, J. C. S. The Specificities of Geomorphosites and heir Influence on Assessment Procedures: a Methodological comparison. Geoheritage, v. 11, n. 4, p. 2045-2064, 2019. DOI: 10.1007/s12371-019-00411-z

27. SANTOS, F. C. A. Mapeamento Geomorfológico do Geossítio das Guaritas do Camaquã/RS: Subsídios à Geoconservação. Dissertação (Mestrado em Geografia) - Universidade Federal de Pelotas, Pelotas, 2016. 102p.

28. SOUZA, N. P.; SILVA, E. M. G. C.; TEIXEIRA, M. D.; LEITE, L. R.; REIS, A. A.; SOUZA, L. N.; ACERBI JR.; F. W.; RESENDE, T. A. Aplicação do Estimador de Densidade Kernel em Unidades de Conservação na Bacia do Rio São Francisco para análise de focos de desmatamento e focos de calor. In: XVI Simpósio Brasileiro de Sensoriamento Remoto (SBSR), 16., 2013, Foz do Iguaçu. Anais... Foz do Iguaçu: INPE. 2013. p. 4958-4965.

29. THOMAS, M. F. A geomorphological approach to geodiversity - its applications to geoconservation and geotourism. Quaestiones Geographicae, v. 31, n. 1, p.81-89, 2012. DOI: 10.2478/v10117-012-0005-9. 
30. THOMAS, M. F. Sources of geomorphological diversity in the tropics. Revista Brasileira de Geomorfologia. v. 13, n. 3, p. 47-60, 2011. DOI: 10.20502/rbg.v12i0.258

31. TRICART, J. Principes et méthodes de la géomorphologie. 1ํㅡㄹ. Ed. Paris: Masson Ed., 1965. 496p.

32. VERSTAPPEN, H. T.; ZUIDAM, R. A van. ITC System of photo-interpretation. v. 7 (use of aerial photography's geomorphology), chapter 2 (ITC System of Geomorphological Survey). Enschede: International Institute for Aerial Survey and Earth Sciences, 1975.

33. VIEIRA, A.; CUNHA, L. Património Geomorfológico - tentativa de sistematização. In: Seminário Latinoamericano de Geografia Física, 03., 2004, Puerto Vallarta. Anais... Puerto Vallarta, 2004. p. 1-14.

34. VON AHN, M. M.; SIMON, A. L. H. Geomorphological mapping and geodiversity: study at the Minas do Camaquã geosite protection area (Brazil). Revista Brasileira de Geomorfologia, v. 18, n. 2, p. 427-442, 2017. DOI: 10.20502/rbg.v18i2.1137

Esta obra está licenciada com uma Licença Creative Commons Atribuição 4.0 Internacional (http://creativecommons.org/licenses/by/4.0/) - CC BY. Esta licença permite que outros distribuam, remixem, adaptem e criem a partir do seu trabalho, mesmo para fins comerciais, desde que lhe atribuam o devido crédito pela criação original. 